\title{
MOKSLEIVIŲ PATIRTIS LANKANTIS PAS ODONTOLOGĄ
}

\author{
Justina Sinkevičiūtė, Monika Daubaraitė \\ Lietuvos sveikatos mokslu universiteto Medicinos akademijos Odontologijos fakultetas
}

Raktažodžiai: nerimas dèl dantų gydymo, dantų gydymo baimè, socialinė šeimos padètis.

\begin{abstract}
Santrauka
Nuo vaikystės žmonėms reikia nepriekaištingos burnos priežiūros. Gaila, tačiau mokiniai vengia lankytis pas odontologą dèl nerimo, baimès ar nepakankamo pasitikejimo savo odontologu.

Gavus tèvų ir tiriamųjų asmenų sutikimus, atlikta anoniminè I - II gimnazijos klasių mokinių apklausa. Šilalès Simono Gauděšiaus ir Lietuvos sveikatos mokslų universiteto (LSMU) gimnazijose buvo išdalinta 400 anketų, iš jų 331 gauta užpildyta. Duomenys statistiškai analizuoti naudojant SPSS 17.0 versiją. Pirmąją neigiamą odontologinę patirtị atsimena 45,3\% jaunuolių. Mokiniai pas odontologą daugiausia lankosi profilaktiškai - 66,8\%, atsiradus danties skausmui $-28,4 \%$. Nustatytas dantu gydymo baimès paplitimas: $60,7 \%$ apklaustujų nejaučia baimès, vidutinę baimę jaučia $32,6 \%$, o stiprią baimę - $6,6 \%$ mokinių. Labiausiai gąsdinančios procedūros yra nuskausminimas ir dantų gręžimas.

Pusės pacientų odontologiné patirtis yra neigiama ir ị odontologą dažniausiai kreipiasi pavèluotai. Pacientai paprastai jaučia mažą ar vidutinę dantų gydymo baimę.
\end{abstract}

\section{Ivadas}

Siekiant geros bendros sveikatos būklès reikia ir nuolatinès burnos sveikatos priežiūros, todèl būtina du kartus per metus lankytis pas odontologą. Dantu gydytojai ne tik gydo esamas burnos ertmès ligas, nuolatiniai apsilankymai svarbūs todèl, kad būtų užtikrinta minkštujų bei kietųjų audinių būklè, užkertanti kelią sunkesnèms ligoms atsirasti [1]. Tačiau šią sąlygą apsunkina dantų gydymo baimè, kuri lydi ịvairaus amžiaus žmones. Tarp visų baimių populiarumo penktoji vieta tenka dantu gydymo baimei [2]. Dantų gydymo baimé tarp vaikų paplitusi nuo 6\% iki 20\% [3,4]. Pagal 2015 m. šaltinį, baimè daugiausia įgyjama vaikysteje ir paauglysteje [5]. Dantų gydymo nerimas tarptautinèje ligų klasifikacijoje yra įrašytas „specifinių fobijų“ skiltyje [6]. Dantų gydymo baimè yra normali emocinè reakcija, kurią gali sukelti vienas ar keli specifiniai gydymo metodai (gręžimas, adatos). Tai susiję su kontrolès praradimu [3,7,8]. Pacientų, jaučiančių dantų gydymo baimę ar nerimą, jausmų išraiška tokia pat [8]. Odontofobija apibūdinama kaip sunki nerimo forma, kada pacientas nuolat jaučia nerimą, susijusị su specifinèmis dantų gydymo procedūromis (gręžimas, injekcijos) [7]. Dantų gydymo nerimas ir baimè neišskiriami ir vartojami išreikšti tą pati jausmą [9].

Dauguma pacientų patys suvokia, jog baimè yra perdeta ar be priežasties [7]. Tokia baimè, nerimas dažnai siejama su konkrečiais objektais, situacijomis ir veda prie dantu gydymo vengimo ar atskiru gydymo procedūrų atsisakymo [3]. Australijoje du trečdaliai suaugusiujų teigia, kad lankèsi pas odontologą per paskutiniuosius 12 mèn., o 80\% respondentų lankèsi per paskutiniuosius dvejus metus. 16\% Australijos suaugusiųų teigia vengiantys apsilankymų dèl dantų gydymo nerimo ir baimès [1]. Pasak $2017 \mathrm{~m}$. šaltinio, 45\% suaugusiųjų Amerikos gyventojų jaučia vidutinę dantų gydymo baimę, o 10 - 20\% jaučia didelę baimę [10]. Galima daryti prielaidą, jog dantų gydymo baimė patiriama jau vaikystėje ir tęsiasi net subrendus.

Dantų gydymo baimę vaikams sukelia polietiologiniai faktoriai. Nuo vaiko priklausantys faktoriai yra jo amžius, lytis, bendras baimès jausmas, temperamentas, anksčiau patirto dantų gydymo procedūrų skausmas, dėmesio sutelkimas. Aplinka, turinti įtakos, tai tėvų dantų gydymo baimès, kultūra, socialiniai ir ekonominiai aspektai, auginimo būdas. Itakos turi odontologo bei odontologo personalo elgesys, neịprasta gydymo padètis, kvapai bei garsai $[3,6,7]$.

Suaugusieji, kurie bijo dantu gydymo, teigia, jog tokia būsena juos lydi nuo ankstyvos vaikystès. Šeimose, kuriose tètis ar mama bijo dantų gydymo, vaikai taip pat bijo [9], nes neretai tėvai, vaiką atvedę pas odontologą, labiau jaudinasi, nerimauja dèl gydymo ir visas emocijas perduoda vaikams [2]. Tyrimo metu nustatyta, jog bendras dantų gydymo baimès lygis mažéja priklausomai nuo amžiaus: jaunesnio amžiaus žmonès bijo labiau nei vyresnio [14]. Dar vienas tyrimas Saudo Arabijoje pagal modifikuotą dantų nerimo 
skalę parodè, kad 15 metų paaugliai mažiau bijo nei 16 metų, o didesne baime pasižymėjo paaugliai, kurie pas odontologą lankèsi daugiau nei prieš metus. 23\% tirtų 15-16 metų paauglių turejo didelę baimę, tai beveik dvigubai daugiau nei remiantis Didžiosios Britanijos surinktais rezultatais. Toks didelis dantų gydymo baimès paplitimas gali būti grindžiamas sunkiu paauglystès periodu, kai imama labiau nerimauti dèl įvairių dalykų [15]. Norvegijoje buvo bandyta išsiaiškinti 12 - 18 metų paauglių neatvykimo pas odontologą priežastis, nes daugiausia vizitų nepranešę praleisdavo dèl dantų gydymo baimès. Tai rodo, jog labai svarbu iš anksto pastebèti baimès atsiradimą dar vaikystejje ir tèvams tinkamai formuoti supratimą apie profilaktinių apsilankymų svarbą [2].

Dantų gydymo nerimą jaučiantys vaikai yra iššūkis odontologams, tèvams ir visai sveikatos sistemai [4]. Dantu gydymo sékmè baimę jaučiantiems pacientams priklauso nuo odontologo patirties, gebejjimų suvaldyti paciento emocijas. Neišmokus bendradarbiauti su pacientu, vèluoja gydymas ar baigiasi visiška nesėkme [7]. Neigiama ir skausminga ankstesnè gydymo patirtis yra pagrindinès dantų gydymo baimès priežastys [6,7]. Rasa Račienè savo mokslinèje disertacijoje teigia, kad dantų gydymo baimę 12-15 metų vaikai labiau patiria valstybineje įstaigoje nei privačioje klinikoje [2]. Dantu gydymo bijantys vaikai rečiau lankosi pas odontologą, vangiau žiūri ị dantų gydymo reikalingumą $[2,6,9]$.

Stebima tendencija, jog karieso paplitimas didèja koreliuojant su dantų gydymo baime, tačiau mokinių, kurių dantys jau plombuoti, baimè mažesnè [6,9]. Bijantys pacientai dažnai yra drovūs, jaučia gèdą, kaltę ir tuo metu, kai jie nusprendžia, jog laikas apsilankyti pas odontologą, tikètina, jog tokiam pacientui reikès nemažai gana invazyvių procedūrų, dèl ko dantų gydymo baimé gali tik dar sustiprèti, todèl ateityje ir toliau bus vengiama gydymo [9], nors dantų gydymas tobulèja, pacientai patiria mažiau skausmo [2].

Odontologas turètų žinoti apie galimą baimę per pirmajj apsilankymą, tam kad būtų pasirinktas optimalus gydymas, keliantis mažiausiai streso [8]. Jordanijoje atlikto tyrimo rezultatai parodé, kad didžioji dalis 10 - 16 metų paauglių teigia, jog odontologai suteikia reikalingą gydymą, paaiškina atliekamas procedūras, tačiau kas antras nurodè, kad reguliariai nesilanko pas odontologą dèl dantų gydymo baimès. Tokios priežastys, kaip įsitikinimai iš anksto, jog procedūros metu skaudès, kartu ne visiškas pasitikejjimas savo gydytoju, lemia nereguliarius vizitus [11]. Prieš apžiūrèdami pacientą, gydytojai galètų atlikti trumpą apklausą, per kurią pacientai atsakytų i klausimus apie savo baimes. Taip būtų greitai ivertinta galima pacientų baimè [8].

2012 metų straipsnyje teigiama, jog vaikų odontologai geriau susitvarko su vaikų baimèmis, nes jie turi daugiau gydymo būdų, nei bendros praktikos gydytojai odontologai.
Tačiau odontologai baimę gali sumažinti tinkamai parodydami ir apibūdindami naudojamus instrumentus, sumažindami vizito laukimo laiką, pasitelkdami žaislus, naudodami techniką ,Sakyk - rodyk - daryk“, gydymą suskirstydami ị kuo trumpesnius vizitus, nes tai padeda lengviau kontroliuoti gydymą. Šios priemonès neužima daug laiko, jomis lengva pasinaudoti [3]. Svarbu pelnyti vaiko ir tėvų pasitikejjimą, tinkamai išmanyti apie vaikų dantų gydymą, išmanyti psichologinius aspektus [2].

Tyrimų, kuriuose siekiama išsiaiškinti vaikų, paauglių dantų gydymo baimes ir pagrindines lemiančias baimès priežastis, yra labai nedaug. Lietuvoje $2012 \mathrm{~m}$. paskelbta R. Račienès, V. Pečiulienès, R. Bendinskaitès mokslinè publikacija, kurioje aiškinamasi Vilniaus miesto 12 -15 metų mokinių dantu gydymo nerimo ir baimès sąsajos su profilaktiniais apsilankymais, dantu gydymo vieta ir socialiniais veiksniais. Tyrimui buvo naudojama nerimo dèl dantų gydymo skalè, klausimai apie apsilankymus pas odontologą. Rezultatai parodè, kad trečdalis mokinių lankosi pas odontologą profilaktiškai ir panaši dalis apsilanko atsiradus dantų skausmui. Taip pat mažiau jaučiantys nerimą ir baimę linkę atvykti profilaktinès apžiūros. $61 \%$ mokinių lankosi privačiose gydymo ịstaigose, o likusi dalis valstybinèje poliklinikoje, tačiau atsiradus dantų skausmui didesnè dalis kreipiasi ị polikliniką, bet ne ị privačią kliniką. Vaikai, kurie gyvena su abiem tèvais, linkę daugiau ị profilaktinius apsilankymus, o išsiskyrusių tėvų vaikai dažniausiai kreipiasi ị odontologą dèl dantų skausmo. Rezultatai rodè, kad didelè dantų gydymo baimè, neigiami ịsitikinimai, valstybinèje ịstaigoje dirbantis odontologas mažina profilaktinių apsilankymų skaičių ir tik esant dantų skausmui kreipiamasi ị gydytoją [11].

Darbo tikslas: išsiaiškinti vyresniujų klasių mokinių odontologinę patirtį.

\section{Medžiaga ir metodai}

Tiriamajame darbe naudotas anoniminès anketinès apklausos metodas. Anketos pradžioje pateiktas tiriamos temos aktualumas bei tikslas. Paaiškinta, kaip mokiniai turi pažymèti jiems tinkamiausią atsakymo variantą.

Anketą sudare 20 klausimų, kuriuose buvo galima pasirinkti tinkamiausią atsakymą iš $2-6$ galimų variantų. Anketa sudaryta iš dviejų blokų klausimyno. Pirmoje dalyje buvo pateikiami sociodemografiniai klausimai, norint sužinoti tiriamujų lytị, amžių, gyvenamają vietą, šeimos padètị ir narių skaičių. Anketa sudaryta remiantis klausimais ir atsakymais iš jau anksčiau atlikto tyrimo [12]. Antrojoje dalyje buvo pateikiami klausimai, siekiant išsiaiškinti tiriamujų lankymosi pas odontologą dažnį, reikalingumą, emocijas, kurios buvo jaučiamos prieš ir per vizitą. Taip pat pateikti klausimai, naudojantis Modifikuota dantų gydymo baimès 
skale (the Modified Dental Anxiety Scale), kad būtų nustatytas bendras dantu gydymo baimès lygis. Ši skalè yra trumpa, sudaryta iš 5 klausimų ir 5 nuoseklių atsakymo variantų: 1.,,nebijočiau“, 2.,,truputi bijočiau“, 3.,,bijočiau“, 4.,,labai bijočiau“, 5.,,nepaprastai bijočiau“. Atsakymai suvedami i Likerto (Likert) skalę, kur mažiausia reikšmè 5 ir didžiausia 25. Suma didesnè nei 19 balų reiškia, jog pacientas išgyvena didelę baimę ir tai, jog odontologams gali būti reikalinga pagalba sékmingam gydymui [13].

Statistiniai duomenys buvo apdorojami naudojant SPSS

1 lentelè. Mokinių dantų gydymosi patirtis, vizitų apsilankymo priežastys * Koreliacijos reikšmingumo lygmuo 0.01 (dvipusis reikšmingumas).

\begin{tabular}{|c|c|c|c|c|c|c|}
\hline \multirow[t]{2}{*}{ Klausimas } & \multirow{2}{*}{$\begin{array}{c}\text { Atsakymo } \\
\text { variantas }\end{array}$} & \multicolumn{3}{|c|}{$\begin{array}{c}\text { Bendras } \\
\text { N }(\%)\end{array}$} & \multirow{2}{*}{$\begin{array}{l}\text { Šilalè } \\
\text { N (\%) }\end{array}$} & \multirow{2}{*}{$\begin{array}{l}\text { Kaunas } \\
\text { N (\%) }\end{array}$} \\
\hline & & Visi & Mergaitès & Berniukai & & \\
\hline \multirow{3}{*}{$\begin{array}{l}\text { Kokią atsimenate } \\
\text { pirmąją patirti odon- } \\
\text { tologo kabinete? }\end{array}$} & Teigiama & $157(47,4)$ & $91(46,7)$ & $66(48,5)$ & $66(36,9)^{*}$ & $91(59,9)^{*}$ \\
\hline & Neigiama & $150(45,3)$ & $88(45,1)$ & $62(45,6)$ & $98(54,7)^{*}$ & $52(34,2)^{*}$ \\
\hline & Labai bloga & $24(7,3)$ & $16(8,2)$ & $8(5,9)$ & $15(8,4)^{*}$ & $9(5,9)^{*}$ \\
\hline \multirow{2}{*}{$\begin{array}{l}\text { Ar Jums yra skaudejję } \\
\text { dantị, dèl ko buvote } \\
\text { nedelsiant priverstas/- } \\
\text { a kreiptis ị dantų } \\
\text { gydytoją? }\end{array}$} & Taip & $188(56,8)$ & $114(58,5)$ & $74(54,4)$ & $108(60,3)$ & $80(52,6)$ \\
\hline & $\mathrm{Ne}$ & $143(43,2)$ & $81(41,5)$ & $62(45,6)$ & $71(39,7)$ & $72(47,4)$ \\
\hline \multirow{4}{*}{$\begin{array}{l}\text { Kaip dažnai lankotès } \\
\text { pas dantų gydytoją? }\end{array}$} & $\begin{array}{l}\text { Du ir dau- } \\
\text { giau kartų } \\
\text { per metus }\end{array}$ & $190(57,4)$ & $127(65,1)$ & $63(46,3)$ & $92(51,4)$ & $98(64,5)$ \\
\hline & $\begin{array}{l}\text { Kartą per } \\
\text { metus }\end{array}$ & $118(35,6)$ & $58(29,7)$ & $60(4,1)$ & $71(39,7)$ & $47(30,9)$ \\
\hline & $\begin{array}{l}\text { Kartą per } \\
2 \text { metus }\end{array}$ & $15(4,5)$ & $8(4,1)$ & $7(5,1)$ & $9(5,0)$ & $6(3,9)$ \\
\hline & $\begin{array}{l}\text { Rečiau nei } \\
\text { kas } 2 \text { metus }\end{array}$ & $8(2,4)$ & $2(1,0)$ & $6(4,4)$ & $7(3,9)$ & $1(0,7)$ \\
\hline \multirow{4}{*}{$\begin{array}{l}\text { Kokie jausmai apima } \\
\text { lankantis pas dantų } \\
\text { gydytoją? }\end{array}$} & $\begin{array}{l}\text { Nekelia } \\
\text { emocijų }\end{array}$ & $120(36,3)$ & $65(33,3)$ & $55(40,4)$ & $64(35,8)$ & $56(36,8)$ \\
\hline & $\begin{array}{c}\text { Jaučiuosi } \\
\text { gerai }\end{array}$ & $50(15,1)$ & $24(12,3)$ & $26(19,1)$ & $29(16,2)$ & $21(13,8)$ \\
\hline & $\begin{array}{c}\text { Mažas } \\
\text { nerimas }\end{array}$ & $127(38,4)$ & $82(42,1)$ & $45(33,1)$ & $66(36,9)$ & $61(40,1)$ \\
\hline & Labai bijau & $34(10,3)$ & $24(12,3)$ & $10(7,4)$ & $20(11,2)$ & $14(9,2)$ \\
\hline \multirow{4}{*}{$\begin{array}{l}\text { Kas skatina lankytis } \\
\text { pas odontologą? }\end{array}$} & $\begin{array}{c}\text { Rūpi burnos } \\
\text { sveikata }\end{array}$ & $178(53,8)$ & $114(58,5)$ & $64(47,1)$ & $98(54,7)$ & $80(52,6)$ \\
\hline & Šeima & $65(19,6)$ & $30(15,4)$ & $35(25,7)$ & $29(16,2)$ & $36(23,7)$ \\
\hline & \begin{tabular}{|c|}
$\begin{array}{c}\text { Skaudantis } \\
\text { dantis }\end{array}$ \\
\end{tabular} & $58(17,5)$ & $33(16,9)$ & $25(18,4)$ & $43(24,0)$ & $15(9,9)$ \\
\hline & Kita & $30(9,1)$ & $18(9,2)$ & $12(8,8)$ & $9(5,0)$ & $21(13,8)$ \\
\hline \multirow{3}{*}{$\begin{array}{l}\text { Kada lankotès pas } \\
\text { dantų gydytoją? }\end{array}$} & $\begin{array}{c}\text { Profilaktiš- } \\
\text { kai }\end{array}$ & $221(66,8)$ & $130(66,7)$ & $91(66,9)$ & $104(58,1)$ & $117(77,0)$ \\
\hline & $\begin{array}{l}\text { Kai pradeda } \\
\text { skaudèti } \\
\text { danti }\end{array}$ & $94(28,4)$ & $58(29,7)$ & $36(26,5)$ & $62(34,6)$ & $32(21,1)$ \\
\hline & $\begin{array}{c}\text { Kai skauda } \\
\text { dantị ir } \\
\text { vaistai } \\
\text { nepadeda }\end{array}$ & $16(4,8)$ & $7(3,6)$ & $9(6,6)$ & $13(7,3)$ & $3(2,0)$ \\
\hline
\end{tabular}

(angl. Statistical Package for Social Sciences) 17.0 versiją. Analizuojant duomenis skaičiuotos aprašomosios statistikos, tikrintos statistinès hipotezės apie požymių tarpusavio priklausomumą. Statistinių hipotezių tikrinimui pasirinkti reikšmingumo lygmenys $(p) 0,05$ ir 0,01 . Tikrinant koreliacijos ryšius statistinei analizei taikytas Spirmeno (Spearman) $\rho$ koreliacijos koeficientas, kadangi didele dalis skirstiniu netenkino normaliojo skirstinio prielaidų.

\section{Rezultatai}

Demografiniai ir socialiniai duomenys. Iš viso tyrime dalyvavo 331 respondentas. Iš jų 195 mergaitès $(58,9 \%)$ ir 136 berniukai $(41,1 \%)$. Šilalèje mergaičiu buvo 94 (52,5\%), berniuku 85 (47,5\%), o Kaune mergaičiu - 101 $(66,4 \%)$ ir berniuku $-51(33,6 \%)$. Aiškinantis respondentų amžių, didžiausią dalị sudarè 15 metų vaikai $50,5 \%, 16$ metu - 37,2\%, o 14 metu - 12,4\%.

Pagal gyvenamają vietą daugiausia apklaustujų buvo miesto gyventojai 216 $(65,3 \%)$ ir iš užmiesčio 115 (34,7\%). Šilalëje panaši dalis respondentų gyvena mieste $(52 \%)$ ir kaime (48\%). Kauno respondentu gyvena mieste $80,9 \%$ ir užmiestyje 19,1\%.

$80,1 \%$ tiriamuju gyvena su abiem tèvais, su vienu iš tèvų $17,5 \%$. Tik $2,4 \%$ gyvena su globejais ir visi jie buvo iš Šilalès. Su abiem tèvais Kaune gyvena daugiau mokiniu $(86,8 \%)$ nei Šilalèje $(74,3 \%)$, taip pat Kaune mažiau gyvenančių su vienu iš tèvų $(13,2 \%)$ nei Šilalèje $(21,2 \%)$.

Šilalèje rastas statistiškai reikšmingas ryšys $(p<0.01)$, jog užmiestyje gyvenantys mokiniai dažniau gyvena su abiem tèvais, tuo tarpu su vienu iš tèvų ar globejjų daugiau gyvena mieste. Kaune panašaus ryšio nenustatyta.

Mokinių gydymosi patirtis, profilaktiniai apsilankymai. Paauglių dantų gydymosi patirtis: pirmieji prisiminimai, kodèl ir kas skatina lankytis pas odontologą, ar yra tekę kreiptis pagalbos dèl danties skausmo. Rezultatai pateikiami 1 lentelèje.

Didžioji dalis paauglių lankosi privačiame odontologijos kabinete (80,1\%), o 
mažesnè - valstybinèje poliklinikoje (19,3\%). Šilalèje statistškai reikšmingai $(\mathrm{p}<0.01)$ trečdalis gydosi valstybinejje ìstaigoje (27,9\%), o kauniečių net tris kartus mažiau $(9,2 \%)$, nes daugiausia jų lankosi privačiose klinikose $(89,5 \%)$.

Vertinant demografiją, nustatytas statistiškai reikšmingas ryšys, jog paaugliai, gyvenantys su abiem tèvais, dažniausiai eina ị privatų odontologijos kabinetą nei ị valstybinę polikliniką, o vaikai, kurie gyvena su vienu iš tèvų, dažniau lankosi poliklinikoje $(p<0.01)$. Priešingai, Šilaleje pastebètas ryšys, jog paaugliai, gyvenantys su vienu iš tèvų, dažniau lankosi privačioje odontologijos klinikoje $(\mathrm{p}<0.05)$.

Dantų gydymo baimès įvertinimas. Siekiant išsiaiškinti, kaip smarkiai paaugliai jaučia dantų gydymo baimę, buvo naudotasi Modifikuota dantų gydymo baimès skale, kurios minimaliausia reikšmė galèjo būti 5 , o didžiausia 25 balai. Maža baimè 5 - 11, vidutinè $12-18$, o stipri baimè $19-25$ balai. Daugiau nei trečdalis paauglių $(32,6 \%)$ jaučia vidutinę dantų gydymo baimę ir 6,6\% stiprią baimę. Du trečdaliai paaugliu jaučia nedidelę baimę ar jos visai nejaučia $(60,7 \%)$. Pagal amžių, stebima tendencija, jog stiprią baimę jaučia vyresni mokiniai nei jaunesni, o mažą ir vidutinę baimę jaučia daugiau jaunesnių paauglių.

1 pav. matome, jog vidutinę (39,5\%) ir stiprią $(9,7 \%)$ dantų gydymo baimę jaučia didesnè dalis mergaičių nei berniukų. Vyriškos lyties atstovai jaučiasi emociškai geriau lankydamiesi pas odontologą.

Rezultatai rodo, jog statistiškai reikšmingai $(\mathrm{p}<0.01)$ mergaitès labiau bijo dantų gydymo nei berniukai tiek Kaune, tiek Šilalèje. Pastebèta, jog didejjant amžiui didejja baimès jausmas $(\mathrm{p}<0.05)$. Paaugliai, gyvenantys su abiem tevais, jaučia mažesnę baimę, nei gyvenantys su vienu iš tèvų ar globejjais.

Tiriamujų buvo klausiama, ar jiems yra tekę dẻl dantų gydymo baimès atšaukti vizitą pas odontologą. Gauti rezultatai rodo, jog net $85,5 \%$ to nèra tekę daryti, tačiau $13,6 \%$ yra vieną ar keletą kartų atšaukę vizitą, o labai nedidelè dalis $(0,6 \%)$ dažnai dẻl dantų gydymo baimès vengia vizito. Pastebèta, jog Šilalèje gyvenantys paaugliai daugiau atšaukia vizitų dèl dantų gydymo baimès nei kauniečiai.

Paauglių buvo klausiama, kas labiausiai kelia baimę lankantis pas odontologą. Labiausiai gąsdina procedūros, susijusios su gręžimu (32\%), esant nuskausminimui, kuomet naudojamos adatos (25\%). Taip pat ankstesné skausminga gydymo patirtis ar nuolatinis žinojimas, jog procedūros metu gali būti jaučiamas skausmas (28\%). Tiriamieji linkę teigti, jog bijo dèl to, nes nepasitiki savo gydytoju odontologu ar nepatinka jo bendravimas su pacientu (5\%). Kai kurie atsakè, jog baimès jausmo nejaučia ir nebijo jokių odontologinių procedūrų. Buvo atvejų, kurie teigè, kad nemaloni pati aplinka, neịprasta padètis.

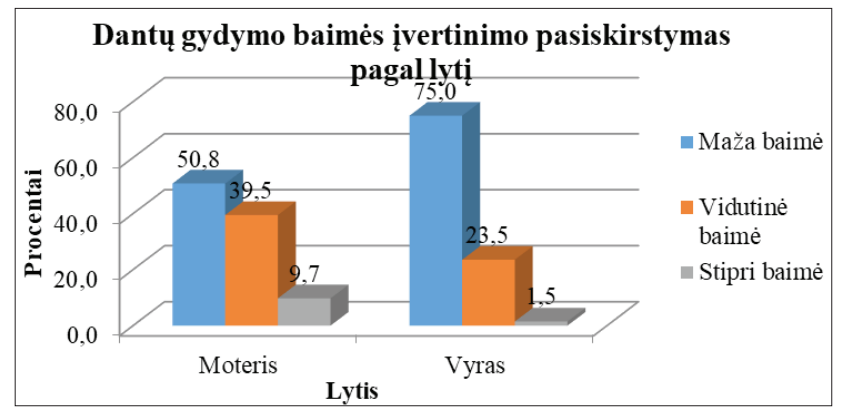

1 pav. Dantų gydymo baimès įvertinimo pasiskirstymas pagal lytị

Mokinių nuomone, odontologo kabinetas mokyklose nèra reikalingas $(72,8 \%)$, kad reikalingas mano tik trečdalis respondentu $(27,2 \%)$. Šilalès mokiniai labiau sutinka su odontologo kabineto nauda $(37,4 \%)$ nei Kauno $(15,1 \%)$.

\section{Diskusija}

Mūsų studijoje beveik kas antras moksleivis savo pirmają odontologinę patirtị ịvardijo kaip neigiamą (45,3\%). Berniukų ir mergaičių emocijos buvo labai panašios. R. Račienè (2009 m.) taip pat nustate, jog 50,4\% moksleivių patyrè neigiamas emocijas ankstesnio gydymo metu ir lygiai taip pat ryškaus skirtumo tarp berniukų ir mergaičių nenustatyta [2].

Galbūt dèl to kas antram paaugliui $(56,8 \%)$ yra tekę kreiptis ị dantų gydytoją dèl dantų skausmo. Lyginant miestus - Šilalès rajono mokiniams yra tekę daugiau dèl šios priežasties kreiptis pagalbos ị gydytoją $(60,3 \%)$ nei Kauno rajono $(52,6 \%)$. Galima manyti, jog provincijos miestelio gyventojai nepakankamai skiria dèmesio burnos sveikatos priežiūrai, galbūt nèra pakankamas odontologų prieinamumas, skausminga ir neigiama ankstesnė gydymo patirtis, dèl kurios jaučiama baimè ir vengiama lankytis profilaktiškai.

Daugiau nei puse respondentų $(57,4 \%)$ profilaktiškai pas odontologą lankosi du ar daugiau kartų per metus, iš kurių didesnioji dalis yra Kauno miesto paaugliai $(64,5 \%)$ nei Šilalès $(51,4 \%)$, o trečdalis lankosi bent vieną kartą per metus ir abiejuose miestuose rezultatai buvo panašūs. R. Račienė (2009 m.) tyrimo metu nustatè, kad pas odontologą per paskutiniuosius metus lankèsi daugiau nei pusè apklaustụjų mokinių $(61,2 \%)$, trečdalis buvo seniau nei prieš metus. Taip pat kaip ir mūsų tyrime, mergaitės linkusios dažniau nei berniukai lankytis profilaktiškai [2]. O V. Moshkelgosha atlikto tyrimo metu net trys ketvirtadaliai apklaustujų bent kartą lankèsi pas odontologą per dvejus metus [16], taigi Lietuvoje profilaktiniai apsilankymai yra dažnesni, geresnis prieinamumas ir pacientų motyvacija.

Nors daugiau nei pusé paaugliu pas dantu gydytoją lankosi dažniausiai profilaktiškai $(66,8 \%)$, tačiau kas trečias kreipiasi tuomet, kai pradeda skaudèti dantị $(28,4 \%)$ 
ar vaistai nebenumalšina skausmo (4,8\%). Priešingai 2012 m. atliktame tyrime tik 30,6\% Vilniaus miesto moksleiviu lankosi profilkatiškai, tiek pat $(28,6 \%)$ vizito atvyksta jau atsiradus danties skausmui - daugiau nei mūsų tyrime, $16,2 \%$ pagalbos ị odontologą kreipiasi tuomet, kai vaistai nuo skausmo nebepadeda [11]. Galima teigti, kad situacija nuo $2012 \mathrm{~m}$. dèl burnos priežiūros profilaktikos gerèja, tačiau išlieka opi problema, nes kreipiamasi ị gydytoją jau esant ligos simptomams.

Didžioji dalis paauglių lankosi privačiame odontologijos kabinete $(80,1 \%)$, o ne valstybineje poliklinikoje $(19,3 \%)$. Stebime, jog privačių gydymo įstaigų pasirinkimas išaugo lyginant su 2012 m., kada privačioje klinikoje gydėsi 61\%, o valstybineje įstaigoje 49\% moksleivių [11]. Lyginant miestus: Šilaleje trečdalis gydosi valstybinèje įstaigoje (27,9\%), o kauniečių tris kartus mažiau $(9,2 \%)$. V. Moshkelgosha atliktame tyrime pusé pacientų teigia besigydantys privačiame odontologijos kabinete, o pasirinkimui įtakos turi draugu rekomendacijos, klinikos pasiekiamumas, kokybė ir dantų gydymo kaina, kuri aktuali mažesnes pajamas gaunantiems pacientams [16].

Vertinant sociodemografinius veiksnius, nustatyta, kad paaugliai, kurie gyvena su abiem tèvais, dažniau eina ị privatų odontologijos kabinetą nei ị valstybinę polikliniką, o vaikai, gyvenantys su vienu iš tèvų, dažniau lankosi poliklinikoje. Toks ryšys nustatytas ir $2012 \mathrm{~m}$. Vilniuje atlikto tyrimo metu [11].

Paklausus apie dantų gydymo baimę, daugiau nei trečdalis jaunuolių (32,6\%) jaučia vidutinę dantų gydymo baimę, o 6,6\% stiprią. Smagu, jog du trečdaliai jaunuolių jaučia nedidelę baimę ar jos visai nejaučia (60,7\%), o Prancūzijoje daugiau nei Lietuvoje 75,7\% 5 - 12 metų amžiaus vaikų jaučia nedidelę, ir mažiau nei Lietuvoje turi 16,7\% vidutinę ir panašiai 7,6\% stiprią dantų gydymo baimę [6]. Australijoje vertinant suaugusiujų dantų gydymo baimę, buvo mažiau jaučiančių stiprią ir vidutinę baimę [17]. Mūsų tyrimo metu stebima tendencija, jog stiprią baimę jaučia vyresni mokiniai nei jaunesni, o mažą ir vidutinę baimę jaučia daugiau jaunesnių paauglių. Tai gali būti susiję su didesne odontologine patirtimi, vyresniems atliekama daugiau procedūrų. Galima daryti prielaidą, jog nemaža dalis paauglių patiria stresą kiekvieno vizito metu.

Vertinant dantu gydymo baimès stiprumo skalę, daugiau mergaičių turi vidutinę $(39,5 \%)$ ir stiprią $(9,7 \%)$ dantų gydymo baimę nei berniukai (23,5\%, 1,5\%). Stebime, jog didèjant amžiui didejja baimès jausmas. Paaugliai, kurie gyvena su abiem tèvais, jaučia mažesnę baimę, nei gyvenančių su vienu iš tėvų ar globejais. Toks pat ryšys nustatytas tiriant 12 - 15 metų Vilniaus moksleivius, kur mergaitès labiau bijo dantų gydymo [2].
Dèl dantų gydymo baimès net $13,6 \%$ yra tekę vieną ar keletą kartų atšaukti vizitą, o labai nedidelè dalis $(0,6 \%)$ dažnai dèl dantų gydymo baimès vengia vizito. Stebima, jog Šilalèje gyvenantys paaugliai daugiau atšaukia vizitų dèl dantu gydymo baimès nei kauniečiai. Galima manyti, jog provincijoje nèra pakankamai odontologų, gyventojai nepakankamai pasitiki gydytojais ar gydymas yra per brangus, kartu dèl neigiamos ankstesnès gydymo patirties neretai bijoma, atidedamas vizitas. Panašius rezultatus matome Australijoje atlikto tyrimo metu, kur respondentai įvardijo, jog dèl laiko trūkumo (20,3\%), brangaus gydymo (45,4\%) vengia vizito pas odontologą, o $12 \%$ ịvardijo dantu gydymo baimę [1].

Pacientus labiausiai gąsdina procedūros, susijusios su gręžimu, esant nuskausminimui, kuomet naudojamos adatos. Ne mažiau baimę kelia skausminga gydymo patirtis ar žinojimas, jog gali būti jaučiamas skausmas. Taip pat tiriamieji teigia, jog nepasitiki savo gydytoju odontologu ar nepatinka jo bendravimas. R. Račienès (2009 m.) tyrime gauta, jog labiausiai nepatinkančios procedūros yra jaučiamas adatos dūris nuskausminant, taip pat gręžimas, jaučiama vibracija. Nustatytas ryšys, jog mergaitės jaučia didesnį nepasitenkinimą nei berniukai [2]. Australijoje respondentai, turintys gydymo fobiją, labai bijo nuskausminimo, adatų ir skausmingų procedūrų [17]. Stebime, jog visame pasaulyje tiek vaikams, tiek suaugusiems didelę baimę kelia tokios pačios procedūros.

\section{Išvados}

1. Pusė apklaustujų paauglių pirmają odontologinę patirtị ịvardija kaip neigiamą. Daugiau nei pusei respondentų pas odontologą yra tekę lankytis dèl atsiradusio nuolatinio danties skausmo.

2. Pusė respondentų reguliariai du kartus per metus lankosi profilaktiškai pas odontologą. Paauglius pas odontologą skatina lankytis rūpinimasis savo burnos sveikata $(53,8 \%)$, taip pat šeimos nariai $(19,6 \%)$ bei atsiradęs danties skausmas $(17,5 \%)$.

3. Daugiau nei pusè paauglių nejaučia dantų gydymo baimès ar turi mažą baimę $(60,7 \%)$, trečdalis jaučia vidutinę dantų gydymo baimę (32,6\%), o 6,6\% patiria stiprią baimę.

\section{Literatūra}

1. Armfield J. The avoidance and delaying of dental visits in Australia. Aust Dent J. 2012 Jun; 57(2): 243-7.

https://doi.org/10.1111/j.1834-7819.2012.01697.x

2. Račienė R. Moksleivių dantų gydymo baimè ir su ja susiję socialiniai bei psichologiniai veiksniai [Disertacija]. [Kaunas]: Kauno medicinos universitetas, Biomedicinos mokslai, visuomenès sveikata; 2009. 
3. Diercke K, Ollinger I, Bermejo JL, Stucke K, Lux CJ, Brunner M. Dental fear in children and adolescents: a comparison of forms of anxiety management practised by general and paediatric dentists. Int J Paediatr Dent 2012 Jan; 22(1): 60-7.

https://doi.org/10.1111/j.1365-263X.2011.01158.x

4. Themessl-Huber M, Freeman R, Humphris G, MacGillivray $\mathrm{S}$, Terzi N. Empirical evidence of the relationship between parental and child dental fear: a structured review and metaanalysis. Int J Paediatr Dent 2010 Mar; 20(2): 83-101.

https://doi.org/10.1111/j.1365-263X.2009.00998.x

5. Hagqvist O, Tolvanen M, Rantavuori K, Karlsson L, Karlsson H, Lahti S. Dental fear and previous childhood traumatic experiences, life events, and parental bonding. Eur J Oral Sci. 2015 Apr; 123(2): 96-101.

https://doi.org/10.1111/eos.12171

6. Nicolas E, Bessadet M, Collado V, Carrasco P, Rogerleroi V, Hennequin M. Factors affecting dental fear in French children aged 5-12 years. Int J Paediatr Dent 2010 Sep 1; 20(5): 366-73. https://doi.org/10.1111/j.1365-263X.2010.01054.x

7. Klingberg G, Broberg AG. Dental fear/anxiety and dental behaviour management problems in children and adolescents: a review of prevalence and concomitant psychological factors. Int J Paediatr Dent.2007 Nov; 17(6): 391-406. https://doi.org/10.1111/j.1365-263X.2007.00872.x

8. Jaakkola S, Rautava P, Alanen P, Aromaa M, Pienihäkkinen K, Räihä H, Vahlberg T, Mattila M, Sillanpää M. Dental fear: one single clinical question for measurement. Open Dent J 2009; 3: 161-166.

https://doi.org/10.2174/1874210600903010161

9. Beaton L, Freeman R, Humphris G. Why are people afraid of the dentist? Observations and explanations. Med Princ Pract 2014; 23(4): 295-301.

https://doi.org/10.1159/000357223

10. Randall CL, Shaffer JR, McNeil DW, Crout RJ, Weyant RJ, Marazita ML. Toward a genetic understanding of dental fear: evidence of heritability. Community Dent Oral Epidemiol 2017; 45: 66-73.

https://doi.org/10.1111/cdoe.12261

11. Račienè R, Pečiulienè V, Bendinskaitè R. Moksleivių kreipimasis ị gydytoją odontologą profilaktinès apžiūros. Psichologiniai ir socialiniai veiksniai (Schoolchildren's preventive dental visits: psychological and social factors). Lietuvos bendrosios praktikos gydytojas, $2012 \mathrm{~m}$. vasaris; 16( 2): 89-94.

12. Goettems ML, Torriani DD, Hallal PC, Correa MB, Demarco FF. Dental trauma: prevalence and risk factors in schoolchildren. Community Dent Oral Epidemiol 2014; 42: 581-590. https://doi.org/10.1111/cdoe.12113

13. American Academy on Pediatric Dentistry Council on Clinical
Affairs. Guideline on management of acute dental trauma. Pediatr Dent 2008-2009; 30(7 Suppl): 175-83.

14. Humphris G, Crawford JR., Hill K, Gilbert A, Freeman R. UK population norms for the modified dental anxiety scale with percentile calculator: adult dental health survey 2009 results. BMC Oral Health 2013; 13: 29.

https://doi.org/10.1186/1472-6831-13-29

15. Abu-Ghazaleh SB, Rajab LD, Sonbol HN, Aljafari AK, Elkarmi RF, Humphris G. The arabic version of the modified dental anxiety scale psychometrics and normative data for $15-16$ year old. Saudi Med J 2011 Jul; 32(7): 725-9.

16. Moshkelgosha V, Mehrzadi M, Golkari A. The public attitude towards selecting dental health centers. J Dent (shiraz) 2014 sep; 15(3): 129-34.

17. Armfield JM. The extent and nature of dental fear and phobia in Australia. Aust Dent J 2010 dec; 55(4): 368-77.

https://doi.org/10.1111/j.1834-7819.2010.01256.x

\section{TEEN EXPERIENCE, WHILE VISITING A DENTIST J. Sinkevičiūtè, M.Daubaraitė}

Key words: dental anxiety, dental fear, social family status, dental trauma, first aid.

Summary

Relevance of the problem and aim of the work. Beginning in their childhood, people need impeccable oral care. Unfortunately, students usually avoid to visit a dentist because of dental anxiety, fear.

Aim. To evaluate adolescents dentistry experience.

Material and the methods. Consents of students and their parents have been received, anonymous survey of 1 st and 2 nd forms of gymnasium students have been made. 400 questionnaires were distributed in Šilale Simonas Gaudešius and LSMU gymnasium, from which 331 were filled. The collected data were statistically analyzed using SPSS version 17.0.

Results. The first negative dental experience remember $45,3 \%$ of teenagers. $66,8 \%$ visit a dentist prophylactically, $28,4 \%$ because of a toothache. The prevalence of dental was established: $60,7 \%$ of respondents feel a small fear. $32,6 \%$ have an average, $6.6 \%$ - strong fear. The most terrifying procedures: anesthesia and tooth drilling.

Conclusions. Half of the patients' dental experience is negative and they go to the dentist too late. Patients usually feel a small or average dental fear.

Correspondence to: juste.mhm@gmail.com

Gauta 2018-06-07 